\title{
Exocrine pancreatic insufficiency and idiopathic haemochromatosis
}

\author{
P. L. M. JANSEN* \\ M.D. \\ C. B. H. W. LAMERS*
M.D. \\ P. REEKERS $\ddagger$ \\ $\mathrm{Ph}$. D
}

\author{
TH. THIEN $\dagger$ \\ M.D. \\ S. H. YAP* \\ M.D. \\ S. STRIJK§
}

*Department of Medicine, Division of Gastrointestinal and Liver Diseases; †Department of Medicine; $¥ B l o o d$ Transfusion Service; and §Department of Radiology, St Radboud Hospital, University of Nijmegen, Nijmegen, The Netherlands

\section{Summary}

The case history of a 34-year-old patient with precirrhotic idiopathic haemochromatosis and severe chronic steatorrhoea is presented. The pancreas had a normal appearance on ultrasonography and endoscopic retrograde pancreaticography. However, pancreatic function tests revealed significant abnormalities. The pancreatic output of trypsin, amylase, lipase and bicarbonate was deficient and basal and stimulated serum pancreatic polypeptide levels were subnormal. In contrast, the oral glucose tolerance test was unimpaired. The pancreatic insufficiency had started suddenly during a summer vacation and may have had a viral aetiology. The hypothesis is advanced that in haemochromatosis the iron-laden pancreatic acinar and PP-producing cells are more susceptible to damage by viruses than normal pancreatic cells.

KEY WORDS: pancreatic polypeptide, viral infection.

\section{Introduction}

Exocrine pancreatic insufficiency is an unusual presenting symptom in idiopathic haemochromatosis. Although diabetes mellitus is common, the exocrine pancreas function is usually spared in haemochromatosis, even when on histological examination the pancreas appears atrophic with iron deposits in both the acinar and islet cells (Axelrod, Ferrucci and Vickery, 1979).

This is a report on a young patient with severe exocrine pancreatic insufficiency and idiopathic haemochromatosis in a precirrhotic stage. The patient did not have diabetes mellitus and no anatomical abnormalities of the pancreas were found on ultrasonography and endoscopic retrograde cholangiopancreatography (ERCP).

\section{Case report}

A 34-year-old male presented with diarrhoea for 5 weeks. He had not experienced any symptoms of viral disease and in particular had not had mumps. Since then he had had liquid stools with the appearance of yellow oil, eight times per day. He had no abdominal or back pains and had maintained his body weight. The alcohol intake was moderate. Four sisters and two brothers were in good health. One sister had been seen by an internist because of a high serum and liver iron content. She had no diarrhoea.

On physical examination the patient appeared thin but otherwise healthy. His body weight was $63.2 \mathrm{~kg}$ and height $1.78 \mathrm{~m}$. He had a fair skin and no abnormalities apart from yellow, liquid, oily stool observed on rectal examination.

The erythrocyte sedimentation rate, haemoglobin, thrombocyte and leucocyte counts, plasma electrolytes, calcium, phosphate, creatinine, liver function tests, protein electrophoretic pattern and serum albumin were all normal. The fat-soluble vitamins were low: vitamin E $12.5 \mu \mathrm{mol} / 1$ (normal 17-34 $\mu \mathrm{mol} / \mathrm{l}$ ) and $25-\mathrm{OH}$-vitamin $\mathrm{D}_{3} 5.7 \mathrm{ng} / \mathrm{ml}$ (normal $>12 \mathrm{ng} / \mathrm{ml}$ ). The thrombotest was $70 \%$. Plasma cholesterol was decreased to $2.9 \mathrm{mmol} / 1$ (normal 4.7-7.3 $\mathrm{mmol} / \mathrm{l}$ ) with normal triglycerides. Vitamin B12 and folic acid levels were normal. Serum iron was increased to $47 \mu \mathrm{mol} / 1$, total iron binding capacity $53 \mu \mathrm{mol} / 1$ (iron saturation $89 \%$ ). The ferritin level was increased to $1,400 \mu \mathrm{g} / 1$ (normal 3-180 $\mu \mathrm{g} / \mathrm{l}$ ). 
The stools contained $60 \mathrm{~g}$ fat per day (normal $<7 \mathrm{~g}$ ) and weighed $430 \mathrm{~g}$ (normal $<200 \mathrm{~g}$ ). Parasitological and bacterial examinations of faeces were negative. The xylose absorption test was normal and the urinary excretion of amylase, indican and aminoacids was within normal limits. An oral glucose tolerance test and a sweat test were normal.

\section{Special studies}

The results of a p-aminobenzoic acid (PABA) test pointed to pancreatic insufficiency. In this test 2 mmol N-benzoyl-L-tyrosyl-p-aminobenzoic acid is administered orally together with a standard meal. In the small intestine this compound is hydrolyzed by pancreatic chymotrypsin and PABA absorbed and excreted by the kidney (Lang, Kraehenmann and Areng, 1980). In a person with a normal functioning pancreas $55 \%$ of the administered dose should be excreted in the urine within $6 \mathrm{hr}$. In the patient this was only $24 \%$. A pancreatic secretin-cholecystokinin stimulation test (Table 1) showed a distinct deficiency of pancreatic enzymes, bicarbonate and of pancreatic fluid volume after secretin.

TABLE 1. Pancreatic secretin-cholecystokinin stimulation test. Basal and stimulated pancreatic output was determined after intraduodenal intubation with a Dreiling tube and collection of duodenal fluid. Two 15-min portions were collected under basal conditions. Four 15-min portions were collected during i.v. secretin infusion $(1 \mathrm{cu} / \mathrm{kg}$ min) and four 15-min portions during secretin + cholecystokinin infusion $(1 \mathrm{cu} / \mathrm{kg} \mathrm{min}$ and 1 Ivy Dog u/ $\mathrm{kg} \mathrm{min}$. respectively). The data are the mean values with normal control values in parenthesis. Trypsin was measured by radioimmunoassay (RIA Gnost) and is expressed in $\mathrm{ng} / \mathrm{min}$; lipase and amylase in $\mathrm{u} / \mathrm{min}$; bicarbonate and bilirubin in $\mathrm{nmol} / \mathrm{min}$; and volume in $\mathrm{ml} / \mathrm{min}$

\begin{tabular}{lcrc}
\hline & Basal output & Secretin & $\begin{array}{c}\text { Secretin }+ \\
\text { cholecystokinin }\end{array}$ \\
\hline Trypsin & $5.9(1448)$ & $11.9(1158)$ & $20.6(5526)$ \\
Lipase & $2 \cdot 1(71.4)$ & $3.3(891)$ & $5 \cdot 1(1792)$ \\
Amylase & $0.5(74.9)$ & $1 \cdot 1(355)$ & $2 \cdot 4(667)$ \\
Bicarbonate & $3 \cdot 2(1.1)$ & $34.6(484)$ & $136(682)$ \\
Bilirubin & $0.3(0.1)$ & $0.4(0.1)$ & $1 \cdot 8(1.5)$ \\
Volume & $1.7(1.5)$ & $1 \cdot 8(4.0)$ & $4.9(6.1)$ \\
\hline
\end{tabular}

Pancreatic polypeptide (PP) in serum was determined under basal conditions and after stimulation with secretin (Fig. 1) or after a standard meal (Fig. 2). The basal serum PP level was very low (5 pmol/1; normal 39.6 $\pm 4.8 \mathrm{pmol} / \mathrm{l}$ ) and showed no response to intravenous administration of secretin. In addition, the response after a standard meal was markedly deficient. The secretin and the meal tests were repeated, 2 and 1.5 years later. A slight recovery of the PP response on a standard meal was observed (Fig. 2) but there was still no response to secretin (Fig. 1). For comparison the test was done in a patient with established haemochromatosis and dia- betes mellitus. He had a normal PP-response to a standard meal (Fig. 2).

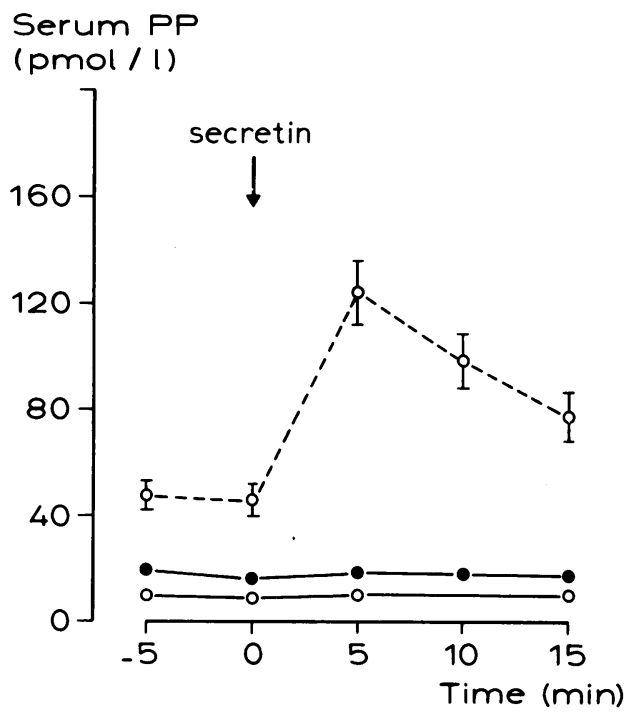

FIG. 1. Pancreatic polypeptide (PP) stimulation test with secretin Serum PP was measured under basal conditions and after i,v. injection of secretin $(1 \mathrm{cu} / \mathrm{kg})$. Two studies were done, 2 years apert (O) March 1981 and (O) March 1983 during which period The patient was treated with phlebotomy. The results are compared wi th those of normal subjects (on $=12$; Lamers, Diemel and Janson 1982).

Endoscopic retrograde pancreatography (ERP)

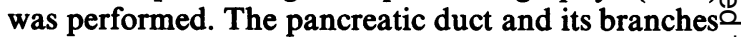
had a somewhat gracile appearance but the ERP waso otherwise normal. An ultrasound study showed no 3 abnormalities in the pancreatic region. A liver biopsy? revealed extensive parenchymal iron deposits (grade? III) with slight fibrosis but no cirrhosis.

A family study was done. None of the seven first. degree family members had clinically overt pan-웅 creatic insufficiency. HLA typing of the patient and his family revealed that the proband was homozymous for the HLA haplotype A3 B7 DR2. The sister mentioned above with the high serum and liver iron? content was HLA identical to the proband. None of the other six siblings had an increased serum iron saturation although two of them must be heterozy- N gotes on the basis of their HLA types.

The patient was treated with weekly phlebotomy, ${ }^{\circ}$ cimetidine and oral supplement therapy with pan- $\omega$ creatic enzymes. On this regimen he felt subjectively better and his stool frequency decreased to once oro twice a day. After a stay of 1 year abroad, where the weekly phlebotomy was continued, the patient was? seen again. He felt well but still needed the pancreatic 0 enzyme supplementation. Stopping the medication $\frac{\vec{\sigma}}{\mathrm{D}}$ 


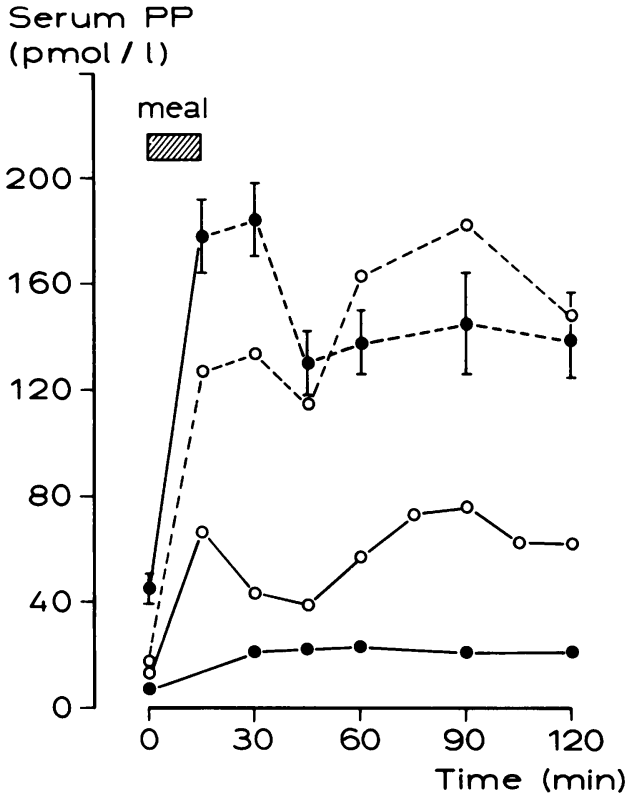

FIG. 2. PP concentrations after ingestion of a standard meal. Serum concentrations were measured before and after the meal. The standard meal consisted of one slice of bread with $50 \mathrm{~g}$ cheese, one boiled egg and $150 \mathrm{ml}$ milk ( $30 \mathrm{~g}$ protein, $25 \mathrm{~g}$ carbohydrates and 20 $\mathrm{g}$ fat). and $\bigcirc$ represents the patient's response in March 1981 and September 1982, respectively. o Represent values from normal subjects $(n=12$; Lamens, Diemel and Jansen, 1982). o- -0 is a PP stimulation test of a 64-year-old male haemochromatosis patient with diabetes mellitus, without steatorrhoea.

resulted in immediate recurrence of the steatorrhoea. His body weight was $69.6 \mathrm{~kg}$, a gain of $6.4 \mathrm{~kg}$.

The laboratory values were as follows: vitamin $\mathrm{E}$, $9.0 \mu \mathrm{mol} / \mathrm{l}$; cholesterol, $3.9 \mathrm{mmol} / \mathrm{l}$; serum iron, 6 $\mu \mathrm{mol} / \mathrm{l}$; total iron binding capacity, $68 \mathrm{mmol} / \mathrm{l}$; serum ferritin, $23 \mu \mathrm{g} / 1$. A PABA test, performed $48 \mathrm{hr}$ after stopping the enzyme substition therapy, was abnormal (14.6\%). Without therapy the stools contained $30 \mathrm{~g}$ fat per day and weighed $330 \mathrm{~g}$. The results of repeated pancreatic function tests are depicted in Figs. 1 and 2 and are discussed above. The oral glucose tolerance test was still normal.

In conclusion, regular phlebotomy resulted in a marked decrease of the serum iron and serum ferritin levels but the exocrine pancreas function was still abnormal except for a slight but significant amelioration of the PP response to a standard meal.

\section{Discussion}

The patient described in this report presented with steatorrhoea. Biochemically there were signs of fat malabsorption. Serum vitamin E, vitamin D3 and cholesterol levels were low. The high daily stool weight and fat content suggested pancreatic insuffici- ency. Therefore, a PABA test was performed and was found to be abnormal. However, small intestinal causes for malabsorption will also result in low PABA excretion in the urine but classical secretin and cholecystokinin stimulation test showed a significant decreased output of trypsin, lipase, amylase and bicarbonate as well as a depressed pancreatic fluid volume. These findings point to pancreatic insufficiency (DiMagno, Go and Summerskill, 1973).

PP release after a standard meal and after intravenously administered secretin was abnormal. A standard meal is a physiological stimulus for PP release by the pancreas. The stimulus reaches the pancreas first via the vagal nerve in the cephalic phase and subsequently via hormones and possibly nerves in the gastric and intestinal phase, resulting in a characteristic biphasic response curve (Scarpello, Vinik and Owyang, 1982). Both the normal group and a 64 year-old diabetic haemochromatosis patient showed such a characteristic curve (Fig. 2). In our patient the response curve was clearly abnormal. In addition secretin, which is a direct stimulus for the PPproducing cells in the pancreas (Floyd and Vinik, 1981) failed to elicit an adequate response. PP is produced in specific cells localized among the exocrine parenchyma and in the islets. Abnormal PP stimulation tests suggest severe destruction of pancreatic tissue (Floyd and Vinik, 1981; Owyang, Scarpello and Vinik, 1982). However, both by ultrasonography and by endoscopic retrograde pancreaticography, the patient's pancreas appeared normal. No calcifications, parenchymal changes, dilated or obstructed ducts were seen. This is an unusual finding in a patient in whom all functional studies and clinical findings point to severe pancreatic insufficiency. The question arose as to the cause of the pancreatic insufficiency.

In chronic pancreatitis advanced changes on ERCP are seen in practically all cases (Belber, 1978). In children steatorrhoea has been described as a result of lipomatous atrophy or pseudohypertrophy of the pancreas (Stafford and Grand, 1982). In these cases the pancreatic ducts appear normal at autopsy. However, this disease has not been reported as an acquired disorder in adults. Another form of pancreatic lipomatosis is Schwachman's syndrome. In this disorder steatorrhoea starts in the first year of life and may disappear later. It is accompanied by neutropenia and recurrent infections. The patients are of short stature and have metaphyseal dysostosis (Schwachman et al., 1964; Hill et al., 1982). Our patient did not show these features. Hereditary pancreatitis with aminoaciduria was also excluded. This is an autosomal dominant disorder (Kattwinkel et al., 1973; Hoek et al., 1981). The family history was negative for steatorrhoea and the patient had no aminoaciduria. A normal sweat test and normal 
serum calcium and phosphate exclude cystic fibrosis and hyperparathyroidism as causes of pancreatic disease. In addition no signs or symptoms of hyperlipoproteinaemia were found. Thus, so far the patient's pancreatic insufficiency appeared "idiopathic".

The patient and a sister were found to have haemochromatosis. Endocrine pancreatic insufficiency leading to diabetes mellitus develops in $30-60 \%$ of patients with idiopathic haemochromatosis (Milder et al., 1980). Although all pancreatic cells may be iron-laden at autopsy, the insulin producing betacells appear to be the most susceptible to the toxic effect of iron. Glucagon production by the alphacells usually remains intact (Nelson et al., 1979). No reports on PP-cell function in haemochromatosis have been published. We found that PP secretion in a diabetic patient with idiopathic haemochromatosis, without signs of exocrine pancreatic insufficiency, was normal. This may indicate that the PP-cells are resistant to damage by iron storage. Thus, haemochromatosis per se does not cause an abnormal PP response. The abnormally low PP response to various stimuli, as was seen in our patient, has been considered an indication of destruction of PP cells. However, he appeared to have a normal pancreatic duct on ERP and ultrasonography. This shows that dysfunction of PP-producing cells and pancreatic exocrine insufficiency does not necessarily imply visible anatomical abnormalities.

Overt exocrine pancreatic insufficiency is seldom seen in idiopathic haemochromatosis. However, lesser degrees of exocrine pancreatic dysfunction may be found such as increased volume excretion (Althausen et al., 1951; Simon et al., 1973) and less often decreased enzyme secretion (Goebell et al., 1971). The finding of overt exocrine pancreatic insufficiency in a young precirrhotic haemochromatotic patient is exceptional. The sudden appearance during a summer vacation suggests a viral origin. Acute pancreatitis in children is sometimes seen in connection with mumps. However, pancreatic dysfunction in this disease is usually reversible and of short duration (Hadorn and Thaler, 1978). Little is known about viral causes of "silent" pancreatic insufficiency. However, it could be that iron-laden pancreatic acinar and PP-producing cells are more susceptible to damage by viruses. Thus we postulate that a virus, contracted during a summer vacation, has caused the exocrine pancreatic insufficiency of this haemochromatotic patient. Although some recovery of PP production after 2 years followup was noted, clinically the exocrine functions were still markedly deficient.

\section{Acknowledgments}

Thanks are due to Dr J. B. M. Jansen, Department of Medicine, Division of Gastrointestinal and Liver Disease, who did the PP assays for us. Furthermore the help of Professor Dr U. J. G. M. van
Haelst from the Department of Pathology, who reviewed the liver histology, is gratefully acknowledged. Thanks are also due to Dr P de Mulder for helpful discussions.

\section{References}

Althausen, T.L., Doig, R.K., Weiden, S., Motteram, R., TurNER, C.M. \& MOORE, A. (1951) Haemochromatosis. Investigation of twenty-three cases, with special reference to etiology, nutrition iron metabolism and studies of hepatic and pancreatic function $\mathbb{D}$ Achives of Internal Medicine, 88, 553.

AXElrod, L., FERruCCI, J.T. \& ViCKery, A.L. (1979) Case 17-1979. New England Journal of Medicine, 300, 969.

BELBER, J.P. (1978) Endoscopic retrograde cholangiopancreaticogra- $\vec{\circ}$ phy (ERCP) and the skinny needle. In: Gastrointestinal disease (Eds.Sleisenger M.H. and Fordtran J.S.), p. 1366. WB Saunders, $\vec{\omega}$ Philadelphia.

DiMaGno, E.P., Go, V.L.W. \& SUMMERSKILl, W.H.J. (1973)을 Relationship between pancreatic enzyme outputs and malabsorp 3 . tion in severe pancreatic insufficiency. New England Journal of
Medicine, 288, 813 . Medicine, 288, 813.

FLOYD, J.C. \& VINIK, A.I. (1981) Pancreatic polypeptide. In: Gur̃ Hormones, (Eds. S. R. Bloom and J. M. Polak), p. 195. ChurchillLivingstone, Edinburgh.

Goebell, H., Bode, CH., LePler, U. \& MARTINI, G. (1971) G Funktionsuntersuchungen des exokrinen Pankreas bei Leberzirrhosen verschiedener Atiologie, Hämochromatose und nach portokavalem Shunt. Acta Hepato-splenologica, 18, 437.

HADORN, B. \& THALER, M.M. (1978) Diseases of the pancreas in childhood. In: Gastrointestinal Disease (Eds. Sleisenger M.H. and? Fordtran J.S.), p. 1488. WB Saunders, Philadelphia.

HiLl, R.E., DURIE, P.R., GASKIN, K.J., DAVIDSON, G.P. \& Forst-足 NER, G.G. (1982) Steatorrhea and pancreatic insufficiency in $^{-}$ Schwachman syndrome. Gastroenterology, 83, $22 . \quad \wp$

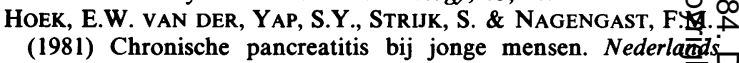
Tijdschrift voor Geneeskunde, 125, 1027.

KATTWINKEL, J., LAPEY, A., Di SANT AGNESE, P.A., EDWARD, W.A. \& HuFTY, M.D. (1973) Hereditary pancreatitis: three new kindreds and a critical review of the literature. Pediatrics, 51, 55,

LAMERS, C.B.H.W., DIEMEL, C.M. \& JANSEN, J.B.M.J. (1982) Serum pancreatic polypeptide responses to food and secretin in patients@ with Billroth I and Billroth II gastrectomies and in normal subjects. Surgery, 91, 288.

LANG, C.A., Kraehenmann, J. \& AREnG, F. (1980) The dual pancreatic function test with N-benzoyl L-tyrosyl-p-aminobenzoic acid: acute toxicity and effects of renal function on this test. Journal of Clinical Chemistry and Clinical Biochemistry, 18, 551.

Milder, M.S., CoOK, J.D., STRAY, S. \& Finch, C.A. (1980) Idiopathic haemochromatosis, an interim report. Medicine, 59, 34

Nelson, R.L., Baldus, W.P., Rubenstein, A.H., Go, V.L.W. \& SERVICE, F.J. (1979) Pancreatic $\alpha$-cell function in diabetic hemochromatotic subjects. Journal of Clinical Endocrinology andô Metabolism, 49, 412.

OWYANG, C., SCARPEllo, J.H. \& VINIK, A.K. (1982) Correlation between pancreatic enzyme secretion and plasma concentration of human pancreatic polypeptide in health and in chronic pancreati- $D$ tis. Gastroenterology, 83, 55.

SCARPELLO, J.H., VINIK, A.I. \& OWYANG, C. (1982) The intestinal phase of pancreatic polypeptide release. Gastroenterology, 82, 406 $\mathrm{N}$ SCHWACHMAN, H., DIAMOND, L.K., OSKI, F.A. \& KHAN, K.T. (1964) The syndrome of pancreatic insufficiency and bone $O$ marrow dysfunction. Journal of Pediatrics, 65, 645.

Simon, M., Gosselin, M., Kerbaol, M., Delanoe, G., Trebaul, L. \& BoUREL, M. (1973) Functional study of exocrine pancreas in idiopathic hemochromatosis, untreated and treated by venesec $\subseteq$ tions. Digestion, 8, 485.

STAFFORD, R.J. \& GRAND, R.J. (1982) Hereditary disease of the exocrine pancreas. Clinics in Gastroenterology, 11, 141.

(Accepted 29 September 1983) 